\title{
Specific work activities and exposure to respiratory hazards - predictors of lung function impairment among crop farmers
}

\author{
Sasho Stoleski*, Jordan Minov, Dragan Mijakoski, Aneta Atanasovska, Dragana Bislimovska, Jovanka Karadzinska-Bislimovska \\ Center for Respiratory Functional Diagnostics, Institute for Occupational Health, World Health Organization Collaborating \\ Center and Ga2len Collaborating Center, Skopje, Republic of Macedonia
}

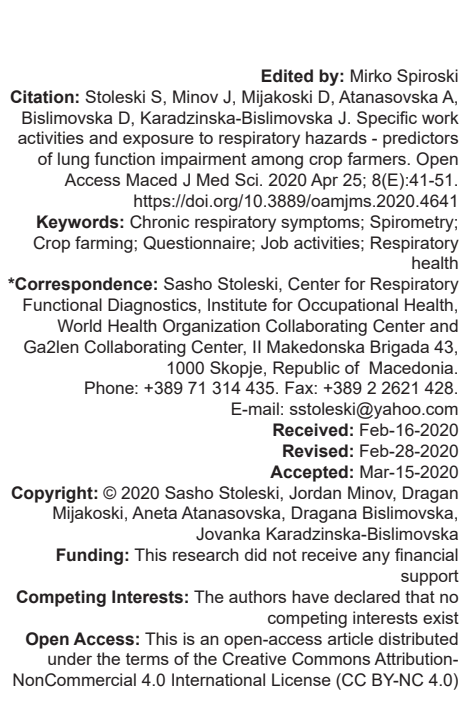

\begin{abstract}
OBJECTIVE: The objective of the study was to evaluate the specific work activities and occupational exposure to respiratory hazards as predictors of chronic respiratory symptoms development, lung function decline, and respiratory health impairment among crop farmers.

METHODS: A cross-sectional survey was performed, including 87 crop farmers (mean age: $53.4 \pm \pm 7.8$ years and mean exposure duration: $22.9 \pm \pm 7.8$ years) and 80 office workers as a control group (mean age: $52.7 \pm$ \pm 8.2 years) matched for age, smoking habits, and socioeconomic status. Subjects were evaluated by a questionnaire on respiratory symptoms in the past 12 months and spirometry testing.

RESULTS: Crop farmers had a significantly higher prevalence of cough (41.4), phlegm (28.7\%), and dyspnea $(21.8 \%)$, than controls $(p<0.05)$. All mean baseline spirometric parameters were lower in crop farmers, but statistical significance was confirmed only for $\mathrm{MEF}_{25}, \mathrm{MEF}_{50}$, and $\mathrm{MEF}_{75}(\mathrm{p}=0.003, p=0.000$, and $p=0.001$, respectively). Most of the respiratory symptoms were significantly associated with common work activities of crop farmers and allday exposure to certain respiratory hazards. Age, exposure duration, and their combined effect with smoking habit had a significant effect on forced expiratory volume in one second $F E V_{1}$ and $F E V_{1} /$ forced vital capacity.

CONCLUSION: The results confirm that occupational exposure among crop farmers is associated with higher prevalence of respiratory symptoms and lung function decline and, together with specific workflow activities, may not only be a predictors of respiratory health impairment, but also a key tool in the creation of preventive strategies.
\end{abstract}

\section{Introduction}

Respiratory hazards are one of the most common occupational hazards in agriculture and can cause different types of respiratory disorders among exposed workers [1]. Farmers are exposed to various inhalation agents: Inorganic soil dust, organic dust containing microorganisms, mycotoxins and allergens, decomposition gases, pesticides, and others. This exposure most often occurs during soil cultivation, harvesting, processing, and storage of grain and other plants, breeding animals, etc. [2].

Exposure to organic dust varies qualitatively and quantitatively, depending on the types of agricultural activities, namely, the grain dust contains molds, spores, mycotoxins, bacteria and their components, excreta, microbes, insects, and animal products. In other cases, grain dust may contain particles of cotton, paper, flour, tobacco, and other dust [3].

Chronic, primarily obstructive pulmonary diseases are nowadays a major clinical and public health problem for agricultural workers, and especially crop farmers. Numerous studies conducted in the last few decades show a significantly higher risk for respiratory morbidity and mortality among crop farmers, demonstrating the link between respiratory hazards in agriculture and not only the development of chronic respiratory symptoms but also the development of chronic respiratory [1].

Breathing problems associated with exposure to dust in farming were first noted and described by Ramazzini in 1713 [4]. In recent decades, chronic respiratory symptoms and diseases have been well known among farmers [5], cattle breeders [6], and pig workers [7], although the magnitude of the problem has not yet been sufficiently assessed [8]. Chronic lung disease in crop farmers can be caused by a wide range of respiratory harmful agents [9], [10].

All of these harmful substances present in the working environment of crop farmers can cause or aggravate: Organic dust toxic syndrome, chronic bronchitis, allergic and non-allergic asthma, asthma-like syndrome, chronic obstructive pulmonary disease 
(COPD), chemical orhypersensitive pneumonitis[11],[12], allergic and non-allergic rhinitis, etc [13].

Data obtained from our previous surveys in this field [14], [15], show that the most common work activities among crop farmers include fieldwork, planting, digging, watering, mechanization and pesticide use, irrigation, harvesting, and cleaning workplaces. During the working process, they are exposed to adverse microclimate conditions, inorganic and organic dust, chemical hazards and pesticides, contact with plants, etc.

Despite the fact that these hazards and dangers are well documented [16], there is little information on the modes and intensity of exposure. Changes in the workflow and farming practices over the last few decades have contributed to a dramatic increase in the concentration of dust and chemical hazards in ambient air [17]. In general, farms are larger, cereal production is increased, and dust, gases, and microorganisms are in high concentrations and represent significant respiratory hazards that play an important role in the development and progression of chronic respiratory diseases [18]

Many epidemiological and clinical studies report a higher prevalence of chronic respiratory symptoms and lung function impairments among agricultural workers compared to other occupations. The frequency of respiratory symptoms depends on the type of farming activity, but mostly on the intensity and length of exposure to organic dust. Research indicates a lower frequency of respiratory symptoms among farmers whose main activity is in growing crops, compared to those engaged in livestock breeding [19].

There is a wealth of data showing that occupational exposure in crop farming may be associated with chronic lung diseases. Dust from cereals and fodder, fertilizer gases, disinfectant vapors, as well as endotoxins and spores from microorganisms are key elements of occupational exposure in crop farmers and identified as likely promoters of airway inflammation [20].

In the present study, we have evaluated specific work activities and occupational exposure to respiratory hazards as predictors of chronic respiratory symptoms development, lung function decline, and respiratory health impairment among crop farmers.

\section{Subjects and Methods}

\section{Study design and setting}

The research team from the Institute for Occupational Health, Skopje - World Health Organization (WHO) Collaborating Center, and GA2LEN Collaborating Center performed a crosssectional survey in the Center for Respiratory Functional
Diagnostics within in the period from August 2018 to February 2019.

\section{Study sample}

To be representative, the study sample was calculated by the software program PEPI 4.04, with $95 \%$ confidence level and confidence interval $(\mathrm{Cl}) \pm 5$.

Aiming to fulfill the requested sample size, and keeping in mind possible selection and response bias, we have taken a representative sample of 87 crop farmers and 80 matched office controls in a large scale agricultural enterprise.

\section{Subjects}

Our research team has examined, 87 subjects (mean age=53.4 \pm \pm 7.8 ) employed as crop farmers (mean duration of exposure $22.9 \pm \pm 7.8$ ). They were engaged in crop farming with main activities composed of cultivating and harvesting crops, planting, digging, use of mechanized equipment, irrigation, cleaning premises, and pesticide handling. Crop farmers were exposed to various respiratory agents, including dust, inappropriate climate and temperature amplitudes, fumes, vapors, and pesticides. Inclusion criteria for examined group (EG) employed subjects with age range 18-64 years involved in dairy farming and exposed to at least one occupational respiratory hazard (dust, gases, fumes, and vapors).

Exclusion criteria for EG subjects younger than 18 or older than 64 years, and subjects not engaged in crop farming were excluded from the study. To avoid selection bias and results' deviations, the study did not include subjects with exposure to respiratory hazards other than crop farming.

Depending on the exposure duration, the examined subjects were divided into two subgroups: Exposed less or more than 20 years.

Furthermore, similar group of 80 office workers (mean age $=52.7 \pm 8.2$ ) matched for age, duration of employment, daily smoking, and socioeconomic status was studied as a control group (CG), with no data on occupational exposure to respiratory hazards.

Subjects in both groups, diagnosed by a physician to have some chronic respiratory disorder (asthma, COPD, bronchiectasis, sarcoidosis, etc.), or treated with bronchodilators and/or corticosteroids were excluded from the study. Furthermore, both groups did not comprise any subjects in whom spirometry testing was contraindicated.

The Institute Ethics Committee has approved our study protocol, whereas each examined subject was informed and gave written consent before proceeding any involvement in the survey. 


\section{Questionnaire}

All study subjects were interviewed by physician and completed the standardized questionnaire, including questions on work history, respiratory symptoms in the past 12 months, and smoking habits.

Chronic respiratory symptoms in the past 12 months (cough, phlegm, dyspnea, wheezing, and chest tightness) were obtained using the European Community for Coal and Steel questionnaire (ECCS-87), and the European Community Respiratory Health Survey questionnaire [21], [22].

Smoking status was classified according to the WHO guidelines on its' definitions [23]. Daily smoker was defined as a subject who smoked at the time of the field survey at least once a day, except on days of religious fasting. Among daily smokers, lifetime cigarette smoking and daily mean of cigarettes smoked were also assessed. Pack-years smoked were calculated according to the actual recommendations [24].

Ex-smoker was defined as a formerly daily smoker, no longer smokes.

Passive smoking or exposure to environmental tobacco smoke was defined as the exposure of a person to tobacco combustion products from smoking by others [25].

\section{Baseline spirometry}

All study subjects underwent spirometry testing, performed by spirometer Ganshorn SanoScope LF8 (Ganshorn Medizin Electronic GmbH, Germany), measuring forced vital capacity (FVC), forced expiratory volume in one second $\left(\mathrm{FEV}_{1}\right), \mathrm{FEV}_{1} / \mathrm{FVC}$ ratio, and maximal expiratory flow at $50 \%, 75 \%$, and $25-75 \%$ of FVC (MEF ${ }_{50}, \mathrm{MEF}_{75}$, and $\mathrm{MEF}_{25-75}$, respectively), by recording the best result from three measurements of the values of $\mathrm{FEV}_{1}$ within $5 \%$ of each other. The results were expressed as percentages of the predicted values according to the European Community of Coal and Steel norms. The spirometry results were given as percents of their predicted values due to the current European Respiratory Society and American Thoracic Society recommendations including reproducibility and acceptability [26].

\section{Statistical analysis}

The obtained data were analyzed using Statistica for Windows version 7. Continuous variables were expressed as mean values with standard deviation and categorical variables as numbers and percentages. The Chi-square test (or Fisher's exact test) was used for testing differences in the prevalence of respiratory symptoms, while the comparison of spirometric measurements was performed by independent-samples t-test. $p<0.05$ was considered statistically significant. Logistic and multiple linear regression analysis was used to assess the risk for the development of chronic respiratory symptoms related to workflow characteristics in crop farmers and lung function impairment, adjusted for age, exposure duration, and smoking habit. Study variables were checked for normality by Kolmogorov-Smirnov and Shapiro-Wilk's W test.

\section{Results}

An overview of the overall and demographic characteristics of the study subjects is shown in Table 1.

Table 1: Demographics of the study subjects

\begin{tabular}{lll}
\hline Variable & Crop farmers $(\mathrm{n}=87)$ & Office workers $(\mathrm{n}=80)$ \\
\hline Gender/M/F ratio & 3.6 & 2.7 \\
Age range (years) & $20-63$ & $21-64$ \\
Age (years) & $53.4 \pm 7.8$ & $52.7 \pm 8.2$ \\
BMI $\left(\mathrm{kg} / \mathrm{m}^{2}\right)$ & $25.6 \pm 3.5$ & $26.2 \pm 3.7$ \\
Duration of employment (years) & $28.2 \pm 8.9$ & $25.3 \pm 9.8$ \\
Duration of exposure & $22.9 \pm 7.8$ & $/$ \\
Daily smokers (\%) & $45(51.7)$ & $39(48.7)$ \\
Life-time smoking (years) & $19.7 \pm 8.1$ & $19.2 \pm 7.8$ \\
Cigarettes/day & $15.4 \pm 7.3$ & $14.8 \pm 7.2$ \\
Pack-years smoked & $13.1 \pm 4.8$ & $12.9 \pm 4.9$ \\
Ex-smokers (\%) & $12(13.8)$ & $12(15)$ \\
Passive smokers (\%) & $11(12.6)$ & $8(16)$ \\
\hline Numerical data are expressed as mean value with standard deviation; frequencies as number and \\
percentage of study subjects with certain variable. BMI: Body mass index; kg: Kilogram; m: meter, \\
OR: Odds ratio, Cl: Confidence interval.
\end{tabular}

Neither diagnose of any chronic respiratory nonoccupational disease (sarcoidosis, tuberculosis) established before the study nor treatment with oral corticosteroids, bronchodilators, antihistamines, or any other medications that could potentially influence the functional and clinical findings were reported by the study subjects.

The frequency of chronic respiratory symptoms in the past 12 months is higher in crop farmers compared to office controls, with a significant difference for cough, cough with phlegm, and dyspnea (Table 2). The association of respiratory symptoms and exposure duration among dairy farmers is shown in Table 2.

Table 2: Prevalence of respiratory symptoms in the past 12 months in both examined groups and prevalence of respiratory symptoms in the past 12 months in crop farmers with the duration of workplace exposure more and $<20$ years

\begin{tabular}{|c|c|c|c|c|}
\hline $\begin{array}{l}\text { Respiratory symptoms } \\
\text { in the past } 12 \text { months }\end{array}$ & $\begin{array}{l}\text { Crop farmers } \\
n=83(\%)\end{array}$ & $\begin{array}{l}\text { Office workers } \\
n=80(\%)\end{array}$ & OR $(95 \% \mathrm{Cl})$ & $p$-value* \\
\hline $\begin{array}{l}\text { Any respiratory } \\
\text { symptom }\end{array}$ & $38(43.7)$ & $23(21.2)$ & $1.81(0.91-3.61)$ & 0.067 \\
\hline Cough & $36(41.4)$ & $17(24.3)$ & $2.72(1.30-5.75)$ & 0.003 \\
\hline Phlegm & $25(28.7)$ & $12(15)$ & $2.28(1.00-5.31)$ & 0.032 \\
\hline Dyspnea & 19 (21.8) & $8(10)$ & $2.51(0.96-6.75)$ & 0.037 \\
\hline Wheezing & $14(16.1)$ & $8(10)$ & $1.73(0.63-4.83)$ & 0.244 \\
\hline Chest tightness & $9(10.3)$ & $6(7.5)$ & $1.42(0.51-3.70)$ & 0.520 \\
\hline \multicolumn{5}{|l|}{ Crop farmers } \\
\hline $\begin{array}{l}\text { Respiratory symptoms } \\
\text { in the past } 12 \text { months }\end{array}$ & $\begin{array}{l}\text { Exposed }>20 \\
\text { years } n=66(\%)\end{array}$ & $\begin{array}{l}\text { Exposed } \leq 20 \\
\text { years } n=21(\%)\end{array}$ & OR $(95 \% \mathrm{Cl})$ & $p$-value ${ }^{*}$ \\
\hline $\begin{array}{l}\text { Any respiratory } \\
\text { symptom }\end{array}$ & $33(50)$ & $5(23.8)$ & $3.20(0.95-11.41)$ & 0.035 \\
\hline Cough & $32(48.5)$ & $4(19.1)$ & $4.00(1.10-15.87)$ & 0.017 \\
\hline Phlegm & $23(34.8)$ & $2(9.5)$ & $6.44(1.28-45.62)$ & 0.008 \\
\hline Dyspnea & $17(25.7)$ & $2(9.5)$ & $3.30(0.63-22.84)$ & 0.141 \\
\hline Wheezing & $12(18.2)$ & $2(9.5)$ & $2.59(0.47-18.59)$ & 0.326 \\
\hline Chest tightness & $7(10.6)$ & $2(9.5)$ & $1.13(0.19-8.63)$ & 0.887 \\
\hline
\end{tabular}


The risk for the development of chronic respiratory symptoms is about three-fold higher among crop farmers exposed more than 20 years compared to those with shorter job exposure (odds ratio [OR] $=3.20$ [0.95-11.41] Cl 95\%).

Crop farmers have lower mean values of spirometric parameters compared to controls, but being significantly only for $\mathrm{MEF}_{25}, \mathrm{MEF}_{50}$, and $\mathrm{MEF}_{75}$ (Table 3).

Table 3: Mean values of spirometric parameters in examined groups and mean values of spirometric parameters in crop farmers with the duration of workplace exposure more and $<20$ years

\begin{tabular}{|c|c|c|c|}
\hline Spirometric parameter & $\begin{array}{l}\text { Crop farmers } \\
(n=87)\end{array}$ & $\begin{array}{l}\text { Office workers } \\
(n=80)\end{array}$ & p-value* \\
\hline FVC (\% pred.) & $92.4 \pm 9.7$ & $94.3 \pm 9.9$ & 0.208 \\
\hline $\mathrm{FEV}_{1}(\%$ pred. $)$ & $85.8 \pm 9.1$ & $87.2 \pm 8.9$ & 0.312 \\
\hline $\mathrm{FEV}_{1} / \mathrm{FVC} \%$ & $73.6 \pm 4.5$ & $74.9 \pm 5.1$ & 0.079 \\
\hline $\operatorname{MEF}_{25}(\%$ pred. $)$ & $57.4 \pm 7.3$ & $60.7 \pm 6.9$ & 0.003 \\
\hline $\mathrm{MEF}_{50}$ (\% pred.) & $57.8 \pm 7.5$ & $61.9 \pm 7.1$ & 0.000 \\
\hline $\mathrm{MEF}_{75}(\%$ pred. $)$ & $58.6 \pm 6.9$ & $62.3 \pm 7.2$ & 0.001 \\
\hline $\mathrm{MEF}_{25-75}$ (\% pred.) & $61.7 \pm 7.9$ & $64.2 \pm 8.3$ & 0.047 \\
\hline \multicolumn{4}{|l|}{ Crop farmers } \\
\hline Spirometric parameter & $\begin{array}{l}\text { Exposed }>20 \\
\text { years }(n=66)\end{array}$ & $\begin{array}{l}\text { Exposed } \leq 20 \\
\text { years }(n=21)\end{array}$ & $p$-value ${ }^{\star}$ \\
\hline FVC (\% pred.) & $91.2 \pm 9.3$ & $92.7 \pm 8.8$ & 0.516 \\
\hline $\mathrm{FEV}_{1}(\%$ pred. $)$ & $84.7 \pm 8.5$ & $86.1 \pm 7.9$ & 0.505 \\
\hline $\mathrm{FEV}_{1} / \mathrm{FVC} \%$ & $72.7 \pm 3.3$ & $74.4 \pm 4.4$ & 0.044 \\
\hline $\mathrm{MEF}_{25}(\%$ pred. $)$ & $56.9 \pm 7.1$ & $57.8 \pm 6.9$ & 0.611 \\
\hline $\operatorname{MEF}_{50}$ (\% pred. $)$ & $55.4 \pm 6.9$ & $58.9 \pm 7.1$ & 0.047 \\
\hline $\mathrm{MEF}_{75}$ (\% pred.) & $56.2 \pm 7.3$ & $52.3 \pm 6.3$ & 0.030 \\
\hline $\mathrm{MEF}_{25-75}$ (\%pred.) & $59.2 \pm 7.2$ & $62.8 \pm 6.9$ & 0.047 \\
\hline
\end{tabular}

Mean values of spirometric parameters in crop farmers with exposure duration of more than 20 years, and those with $<20$ years are given in Table 3 .

Results are presented in Table 3 confirm that mean values of spirometric parameters among crop farmers exposed more than 20 years are lower than in those with exposure $<20$ years with a significant difference for $\mathrm{MEF}_{50}$ and $\mathrm{MEF}_{75}$.

The effect of occupational exposure on crop farmers is monitored by their exposure to certain respiratory hazards and their occupational activities, each exposure individually, and combinations of exposure to several occupational respiratory hazards at the same time. Data on exposure to respiratory hazards, as well as the work activities they perform, are obtained from the self-reported questionnaire on occupational exposure to respiratory hazards.

According to questionnaire data, 87 crop farmers are engaged to work mainly in the open field for growing cereals and/or industrial crops. Their daily work includes activities such as digging, planting and weeding, watering, harvesting, harvesting of fruits, using agricultural machinery, cleaning workplaces, and so on. In addition, they are exposed to a wide range of respiratory hazards such as dust, temperature amplitudes, pesticides, fertilizers, fodder, exhaust, moisture, draft, and others.

Table 4 shows the association of several specific work activities in crop farmers with the occurrence of chronic respiratory symptoms.

Logistic regression shows that most of the chronic respiratory symptoms are significantly associated with the most common work activities of crop farmers, such as digging and watering, planting and weeding, harvesting and cleaning of premises, taking into account differences caused by age, gender, and smoking habits.

The distribution of chronic respiratory symptoms associated with workflow characteristics in crop farmers is shown in Table 5, through the prevalence ORs, after adjusting for age, gender, and smoking habits.

Table 5 shows that in the case of all-day exposure among crop farmers, the risk of developing phlegm, dyspnea, and wheezing significantly increases. Exposure to gases significantly increases the risk of coughing and wheezing, while exposure to smoke and vapors significantly affects the appearance of phlegm and dyspnea. Dust exposure significantly increases the risk of coughing, phlegm, and wheezing, pesticides are significantly associated with chest tightness, while fertilizers are non-significantly associated with the occurrence of any chronic respiratory symptoms.

There was no difference in crop farmers with respect to types of cultivated crops (cereal and/or industrial), and both increased the risk of coughing and wheezing in exposed workers by two-fold.

The effect of occupational exposure duration to respiratory hazards, smoking, and age on functional lung parameters in crop farmers is shown in Table 6.

Linear regression shows that age, exposure duration, and the combined effect of age, exposure duration, and smoking habit have a significant effect on $\mathrm{FEV}_{1}$ and $\mathrm{FEV}_{1} / \mathrm{FVC}$, and have no significant effect on

Table 4: Relationship between respiratory symptoms with certain specific work activities of crop farmers, adjusted for age, gender, and smoking habit

\begin{tabular}{|c|c|c|c|c|c|c|}
\hline Symptoms & $\begin{array}{l}\text { Digging and watering } \\
\text { OR }(95 \% \mathrm{Cl})\end{array}$ & $\begin{array}{l}\text { Planting and weeding } \\
\text { OR }(95 \% \mathrm{CI})\end{array}$ & $\begin{array}{l}\text { Mechanization use } \\
\text { OR }(95 \% \mathrm{Cl})\end{array}$ & $\begin{array}{l}\text { Pesticide use } \\
\text { OR }(95 \% \mathrm{Cl})\end{array}$ & $\begin{array}{l}\text { Harvesting OR } \\
(95 \% \mathrm{Cl})\end{array}$ & $\begin{array}{l}\text { Cleaning workplaces } \\
\text { OR }(95 \% \mathrm{Cl})\end{array}$ \\
\hline $\begin{array}{l}\text { Any respiratory } \\
\text { symptoms }\end{array}$ & $\begin{array}{l}2.45^{\star} \\
(1.21-5.16)\end{array}$ & $\begin{array}{l}2.23^{*} \\
(1.12-4.68)\end{array}$ & $\begin{array}{l}1.72 \\
(0.81-3.89)\end{array}$ & $\begin{array}{l}1.92 \\
(0.80-4.32)\end{array}$ & $\begin{array}{l}3.39^{*} \\
(1.13-5.34)\end{array}$ & $\begin{array}{l}2.35^{\star} \\
(1.04-4.72)\end{array}$ \\
\hline Cough & $\begin{array}{l}2.41^{*} \\
(1.13-4.87)\end{array}$ & $\begin{array}{l}2.24^{*} \\
(1.34-4.67)\end{array}$ & $\begin{array}{l}1.68 \\
(0.41-4.72)\end{array}$ & $\begin{array}{l}1.89 \\
(0.71-4.54)\end{array}$ & $\begin{array}{l}4.19^{*} \\
(1.15-6.43)\end{array}$ & $\begin{array}{l}2.86^{*} \\
(1.35-6.12)\end{array}$ \\
\hline Phlegm & $\begin{array}{l}2.28^{*} \\
(1.14-4.39)\end{array}$ & $\begin{array}{l}2.09^{*} \\
(1.12-3.98)\end{array}$ & $\begin{array}{l}1.68 \\
(0.72-3.38)\end{array}$ & $\begin{array}{l}1.78 \\
(0.0-3.3)\end{array}$ & $\begin{array}{l}2.43^{*} \\
(1.23-4.72)\end{array}$ & $\begin{array}{l}2.09^{*} \\
(0.89-3.83)\end{array}$ \\
\hline Dyspnea & $\begin{array}{l}2.13^{*} \\
(0.92-4.79)\end{array}$ & $\begin{array}{l}1.79 \\
(0.67-4.23)\end{array}$ & $\begin{array}{l}1.54 \\
(0.41-3.2)\end{array}$ & $\begin{array}{l}1.69 \\
(0.45-4.19)\end{array}$ & $\begin{array}{l}2.12^{*} \\
(1.15-4.56)\end{array}$ & $\begin{array}{l}2.02^{\star} \\
(0.91-4.36)\end{array}$ \\
\hline Wheezing & $\begin{array}{l}3.22^{*} \\
(1.23-6.43)\end{array}$ & $\begin{array}{l}2.42^{*} \\
(1.23-5.12)\end{array}$ & $\begin{array}{l}0.85 \\
(0.29-2.81)\end{array}$ & $\begin{array}{l}1.84 \\
(0.72-3.69)\end{array}$ & $\begin{array}{l}2.71^{*} \\
(1.14-6.41)\end{array}$ & $\begin{array}{l}1.89 \\
(0.78-4.15)\end{array}$ \\
\hline $\begin{array}{l}\text { Chest } \\
\text { tightness }\end{array}$ & $\begin{array}{l}1.55 \\
(0.58-3.17)\end{array}$ & $\begin{array}{l}1.63 \\
(0.62-3.41)\end{array}$ & $\begin{array}{l}0.93 \\
(0.23-3.09)\end{array}$ & $\begin{array}{l}2.09 * \\
(0.91-4.28)\end{array}$ & $\begin{array}{l}3.28 \text { * } \\
(1.29-6.34)\end{array}$ & $\begin{array}{l}1.42 \\
(0.57-2.37)\end{array}$ \\
\hline
\end{tabular}


Table 5: Distribution of chronic respiratory symptoms related to workflow characteristics in crop farmers (Prevalence ORs $\left.[95 \% \mathrm{Cl}]{ }^{*}\right)$

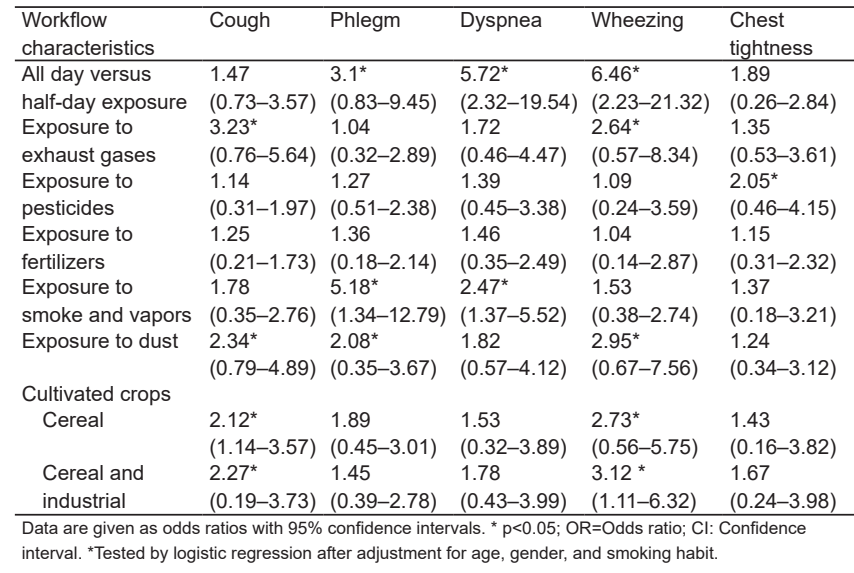

FVC. Other spirometric parameters $\left(\mathrm{MEF}_{25-75}\right.$ and peak expiratory flow) are significantly affected only by age and the combined effect of age, exposure duration, and smoking habit.

Table 6: Effect of exposure duration, smoking habit, and age on spirometric parameters in crop farmers

\begin{tabular}{|c|c|c|c|c|}
\hline Spirometric parameters & $\mathrm{R}^{2}$ & Intercept & Beta & $\mathrm{p}^{*}$ \\
\hline \multicolumn{5}{|l|}{ FVC } \\
\hline Age & 0.00172247 & 10.308879824 & -0.04 & 0.703 \\
\hline Exposure duration & 0.00000003 & 7.368228159 & -0.00 & 0.057 \\
\hline $\begin{array}{l}\text { Smoking habit (cigarettes/daily/years } \\
\text { smoking) }\end{array}$ & 0.01696245 & 6.198750000 & -0.11 & 0.492 \\
\hline $\begin{array}{l}\text { Combined effect of age, exposure } \\
\text { duration, and smoking habit }\end{array}$ & 0.02204462 & 12.046183454 & -0.12 & 0.767 \\
\hline \multicolumn{5}{|l|}{$\mathrm{FEV}_{1}$} \\
\hline Age & 0.24871322 & 9.435893260 & -0.50 & $0.000^{*}$ \\
\hline Exposure duration & 0.11681759 & 6.078983027 & -0.34 & $0.002^{*}$ \\
\hline $\begin{array}{l}\text { Smoking habit (cigarettes/daily/years } \\
\text { smoking) }\end{array}$ & 0.02044532 & 4.557187500 & -0.12 & 0.424 \\
\hline $\begin{array}{l}\text { Combined effect of age, exposure } \\
\text { duration, and smoking habit }\end{array}$ & 0.26431033 & 9.955227346 & -0.64 & $0.000^{*}$ \\
\hline \multicolumn{5}{|l|}{$\mathrm{FEV}_{1} / \mathrm{FVC} \%$} \\
\hline Age & 0.51756808 & 86.593508450 & -0.72 & $0.000^{*}$ \\
\hline Exposure duration & 0.43955176 & 81.467963735 & -0.66 & $0.000^{*}$ \\
\hline $\begin{array}{l}\text { Smoking habit (cigarettes/daily/years } \\
\text { smoking) }\end{array}$ & 0.01859051 & 77.768750000 & -0.16 & 0.459 \\
\hline $\begin{array}{l}\text { Combined effect of age, exposure } \\
\text { duration, and smoking habit }\end{array}$ & 0.53820620 & 85.630665634 & -0.53 & $0.000^{*}$ \\
\hline \multicolumn{5}{|l|}{$\mathrm{MEF}_{25-75}$} \\
\hline $\mathrm{Age}^{25-15}$ & 8.424212459 & 0.10357836 & -0.32 & 0.002 * \\
\hline Exposure duration & 0.03590505 & 5.439568709 & -0.19 & 0.079 \\
\hline $\begin{array}{l}\text { Smoking habit (cigarettes/daily/years } \\
\text { smoking) }\end{array}$ & 0.01253450 & 4.551250000 & -0.08 & 0.592 \\
\hline $\begin{array}{l}\text { Combined effect of age, exposure } \\
\text { duration, and smoking habit }\end{array}$ & 0.17159695 & 9.349073257 & -0.49 & 0.009 * \\
\hline \multicolumn{5}{|l|}{ PEF } \\
\hline Age & 0.10201770 & 839.65815494 & -0.32 & $0.000^{*}$ \\
\hline Exposure duration & 0.04029379 & 559.24635210 & -0.20 & 0.063 \\
\hline $\begin{array}{l}\text { Smoking habit (cigarettes/daily/years } \\
\text { smoking) }\end{array}$ & 0.01234068 & 461.81250000 & -0.12 & 0.597 \\
\hline $\begin{array}{l}\text { Combined effect of age, exposure } \\
\text { duration, and smoking habit }\end{array}$ & 0.13732087 & 894.83228294 & -0.44 & $0.034^{*}$ \\
\hline
\end{tabular}

\section{Discussion}

Our study evaluated the effects of specific work activities and occupational exposure to respiratory hazards on the occurrence of chronic respiratory symptoms and lung functional impairments among exposed crop farmers. The CG consists of an adequate number of unexposed persons (office workers) complementary to those exposed by sex and age. In both groups, there is a relatively high prevalence of active smokers (about 50\%) and is slightly higher than in the previous studies by Stoleski et al. among agricultural workers [27], [28], [29].

The prevalence of subjects with chronic respiratory symptoms in our study, among EG was $43.7 \%$, of which approximately $68 \%$ indicated their work-related exacerbation. The prevalence of subjects in CG with respiratory symptoms was $28.7 \%$, with no association of symptoms with work. The prevalence of overall symptoms was higher in EG subjects, and a significant difference was reported for cough, phlegm, and dyspnea. In a study of 240 feed production workers exposed to high average dust concentration $(16.8 \mathrm{mg} / \mathrm{m} 3)$, Kuchuk et al. report a prevalence of chronic bronchitis of $26.4 \%$ [19].

Chronic respiratory and nasal symptoms and chronic pulmonary diseases still represent important clinical and public health problems for agricultural workers [1]. According to studies across Europe, the prevalence of chronic respiratory symptoms varies from $25 \%$ to $35 \%$ [30], while according to research by Stoleski et al. dedicated to agricultural workers in the Skopje region, it is $26.6 \%$ [27]. The prevalence of phlegm in farmers in the above-mentioned study was $8.3 \%$, which is similar not only to some previous studies in our country dedicated to the respiratory effects caused by specific occupational exposure in agricultural workers but also to those in Slovenia and Croatia [31]. According to the results of a Dutch study, the incidence of phlegm in farmers is $2-12 \%$ depending on the main activity; it is highest among livestock breeders [30]. The prevalence of phlegm in finnish farmers is 7.5\% [32], up to $23 \%$, according to a study in Manitoba, Canada [33]. According to the results of a finnish study conducted as a follow-up after 3 years, the prevalence of phlegm is higher, with an annual incidence rate of $2 \%$. The survey in Denmark included a sample of 834 men from the general population, aged 65-84 years, with the highest prevalence of phlegm among retired agricultural workers [34].

Research in France shows the highest prevalence of dyspnea among farmers $(37 \%)$, industrial workers (31\%), and lowest among teachers (15\%) [35], similar to studies showing a higher frequency of chronic cough among farmers [36], [37]. A survey in Poland examining cereal growers (sowing, irrigation, harvesting, and collecting) showed a prevalence of $44.7 \%$ for chronic respiratory symptoms, with the highest rates being recorded for chronic cough (26.3\%) and dyspnea (19.7\%) [38]. Many other studies also confirm the high prevalence of wheezing among agricultural workers compared to office workers [39]. In the study of Stoleski et al. [27], a higher prevalence of overall chronic respiratory symptoms in agriculture compared to office 
workers has been found, with a significant difference for cough and wheezing.

According to the study by Stoleski et al. about chronic respiratory symptoms and bronchial hyperreactivity in agricultural workers in the R. Macedonia, with particular reference to their intensity and relationship to occupational exposure [28], the prevalence of overall chronic respiratory symptoms in cattle breeders is $31.6 \%$, which is similar to surveys across Europe, where their frequency varies with farmers from $25 \%$ to $35 \%$ [30]. In general, many studies around the world, such as those conducted in New Zealand, Germany, Spain, and other countries [36], [40], [41], confirm the higher prevalence of work-related chronic respiratory symptoms in farmers, and certain differences are likely due to regional differences, differences in exposure or possibly the use of different farming and livestock methods and techniques of operation. Studies in this regard show a higher prevalence of chronic bronchitis in livestock and cattle breeders compared to farmworkers [19]. The prevalence of overall respiratory symptoms in the study by Stoleski et al. dedicated to the impact of smoking and the length of occupational exposure on respiratory symptoms and lung functional impairments among farmworkers [29] accounted for $29.3 \%$. Cough is present at $20 \%$, phlegm in $10.7 \%$, while the prevalence of dyspnea, wheezing, and chest tightness is $12 \%, 10.7 \%$, and $8 \%$, which is quite similar to the prevalence of registered selfreported respiratory symptoms in a study of European animal farmers [42], confirming the association between occupational exposure and the development of chronic respiratory symptoms.

In this regard, the study by Danuser et al. concludes that agricultural work in Swiss farmers is closely linked to the risk of developing chronic bronchitis and four and a half times higher risk of phlegm compared to the general population [43]. In any case, the prevalence of chronic respiratory symptoms does not always correspond to the degree of impaired airflow detected by spirometry.

Another study examining, the prevalence of chronic bronchitis among agricultural workers is that of Kern et al. [44]. It includes subjects working on a farm but not involved in livestock breeding, and the results are compared with those engaged in food packaging. The study found a significantly higher prevalence of chronic bronchitis in men in the study group (20.9\%) compared with the CG $(7.4 \%)$. On the other hand, smokers had a significantly higher prevalence of chronic bronchitis $(30.2 \%)$ compared to non-smokers $(6.9 \%)$.

Significantly, the higher incidence of respiratory symptoms in men than in women exists only in EG. The prevalence of phlegm in both groups was significantly higher in men. The results are similar to those in studies with respondents with specific occupational exposure to organic and inorganic dust [45].

The risk of developing respiratory symptoms is approximately 3 times higher in EG subjects with exposure more than 20 years, compared to those with shorter exposure. The risk of developing respiratory symptoms is about 3 times higher in exposed subjects in EG who are active smokers compared to nonsmokers. Out of the individual chronic respiratory symptoms, the length of exposure over 20 years in EG is significantly associated with cough and phlegm, whereas active smoking correlates significantly with cough and phlegm. A significant association between exposure length and chronic bronchitis has been reported in the study by Omland et al. with 1691 farmers exposed to vegetable and animal dust [46]. Chronic respiratory symptoms in agricultural workers in the study of Stoleski et al. [27] are significantly related to the length of occupational exposure over 20 years, age over 60 years, exposure to chemical hazards, and smoking habits in men. Many studies indicate a higher frequency of chronic respiratory symptoms in agricultural workers with longterm occupational exposure [47], while those examining the respiratory effects of different types of organic dust speak of a significant association between smoking habit and chronic respiratory symptoms [48], [49]. Farmers' research in France shows a synergistic effect of occupational exposure and smoking, especially for cough and phlegm, while a similar study in Canada indicates a significant association between phlegm, dyspnea, and wheezing among agricultural workers [33]. In the study of Stoleski et al., the incidence of active smokers among agricultural workers is $26.7 \%$, and the frequency of respiratory symptoms in the past 12 months is higher among agricultural workers with exposure longer than 15 years, but with statistical significance only for overall respiratory symptoms and dyspnea [29].

In the study of Kuchuk et al. among workers engaged in animal feed production, there was a significantly higher prevalence of airflow obstruction in exposed than in non-exposed subjects, being significantly associated with respirable workplace dust concentration [19].

The results of our study indicate lower mean values of all spirometric parameters, with a significant difference for mean values of the small airways parameters $\left(\mathrm{MEF}_{25}, \mathrm{MEF}_{50}, \mathrm{MEF}_{75}\right.$, and $\mathrm{MEF}_{25-75}$ ) in EG compared to CG subjects. The mean values of spirometric parameters were lower in EG subjects exposed longer than 20 years compared to those with shorter exposure, with statistical significance for $\mathrm{FEV}_{1} / \mathrm{FVC} \%, \mathrm{MEF}_{50}, \mathrm{MEF}_{75}$, and $\mathrm{MEF}_{25-75}$. There is a significant difference in the detected ventilatory insufficiency in EG compared to CG for obstructive, combined, predominantly obstructive type of ventilator insufficiency, as well as small airways obstruction. The results are similar to several studies conducted in our country and worldwide with subjects from the general population and subjects with specific occupational exposure [50]. According to the study 
by Karadzinska-Bislimovska et al. among agricultural workers, the prevalence of lung functional impairment is from $23.4 \%$ to $28.8 \%$ [14], while Stoleski et al. in a survey of agricultural workers in rural areas show that respiratory diseases are among the most common, with a prevalence of $23.8 \%$ [15].

ACanadian study of agricultural workers, mainly engaged in cereal cultivation in Manitoba, shows a nonsignificant difference in basic spirometric parameters (VC, FEV ${ }_{1}$, and Tiffeneau index) compared to controls, although they are much lower in agricultural workers [33]. The research of Stoleski et al. in agricultural workers in the Skopje region shows lower mean values of all spirometric parameters than the CG, with a significant difference for the mean values of $\mathrm{MEF}_{50}$ and $\mathrm{MEF}_{75}$, and ventilatory disorders are associated with age over 60 , length of occupational exposure over 20 years, smoking habit, and exposure to dust and pesticides [27]. On the other hand, the research of Dosman et al. [51] on the effect of specific occupational exposure on the frequency of chronic respiratory symptoms and the reduction of functional lung parameters in workers engaged in cereal cultivation in Denmark, recorded significantly lower values of all spirometric parameters (including small airways) compared to controls, and their decrease is significantly related to age and exposure to pesticides. Similar results were obtained in the study of Corey et al., Enarson et al., and Huy et al., regarding the effect of grain dust on the values of spirometric parameters in exposed agricultural workers [52], [53], [54]. Significantly lower VC and $\mathrm{FEV}_{1}$ values in livestock breeders compared to controls were reported in the study by Dalphin et al., exploring the effects of specific occupational exposure in France [55]. Research on agricultural workers in Serbia shows an annual decrease in the value of FEV1 to $44 \mathrm{ml}$ [56]. According to a longitudinal Canadian study of farmworkers in barns and silos, the first decline in the value of FEV1 was recorded after a 2.5-3-year exposure, followed by a progressive further decline in ventilation [39]. The longitudinal study of Dalphin et al. among farmers in France reveals a significant correlation between the decrease in Tiffeneau index values $\left(F E V_{1} /\right.$ FVC\%) with the intensity and length of occupational exposure to organic dust [57]. The mentioned study of farmers in Serbia recorded significantly reduced FVC and $\mathrm{FEV}_{1}$ values compared to control workers, without identifying the effect of smoking habit [56]. The synergy between specific occupational exposure and smoking has been confirmed in many other studies dealing with the respiratory health of agricultural workers. According to the longitudinal study of Tashkin et al. [58], the annual decrease in the value of $F E V_{1}$ is between 7 and $33 \mathrm{~mL}$, depending on the length and intensity of occupational exposure to aeropollutants and tobacco smoke.

In the actual study, obstructive patterns in the small airways in EG were significantly related to the length of exposure, active smoking, and length of smoking experience. The association between obstructive ventilatory insufficiency and small airways obstructive patterns with active smoking among CG subjects is non-significant, suggesting a possible interaction between occupational exposure and tobacco smoke in their occurrence in EG subjects.

The combined effect of smoking, it's duration, and the number of cigarettes smoked per day significantly influence the occurrence of obstructive pattern in the small airways of the EG subjects, while small airways obstructive pattern is significantly associated with the occurrence of cough and phlegm in EG1 and with chronic bronchitis in CG. Similar findings are reported in the study by Omland et al. which investigates the respiratory effects of occupational exposure on farmers [46]. The study by Kuchuk et al. with animal feed production workers exposed to high concentrations of respiratory dust suggests a significant association between obstructive ventilatory insufficiency and small airways obstruction with exposure duration and smoking [19]. The research of Stoleski et al. about chronic respiratory symptoms and bronchial hyperresponsiveness in agricultural workers in the R. Macedonia, with particular reference to their intensity and relationship with occupational exposure, registered lower mean values of spirometric parameters in cattle breeders compared to farmers, with statistical significance for the mean values of $\mathrm{MEF}_{50}$ and $\mathrm{MEF}_{75}$. According to this study, ventilatory disorders are associated with over age 55, smoking habit and occupational exposure to dust, gases, vapors, and pesticides over 25 years [28].

Sigsgaard et al. in the Danish study, young farmers, reported a significant difference between men farmers and men in the CG, while in women farmers basic spirometric parameters were significantly lower than women in the CG [59]. Our previous research [29] confirms the decline in lung functional parameters with increasing the length of exposure, but statistical significance exists only for MEF parameters in farmers who have been exposed for more than 15 years. Gautrin et al. in Canada suggest that there is a positive interaction effect between occupational exposure to cereal cultivation and smoking habit on lung function and the prevalence of chronic bronchitis in women [60]. The research of Stoleski et al. [29] shows a significant association between small airway flow and the combined effect of exposure length, smoking, smoking experience, and number of cigarettes smoked in exposed workers. Furthermore, the research shows that exposure length, smoking, and age have an independent effect only on small airway flow, i.e., on $\mathrm{MEF}_{25-75}$ indices, and not on other spirometric parameters (FVC, $\mathrm{FEV}_{1}$, and $\mathrm{FEV}_{1}$ I FVC\%) [29].

The prevalence of chronic bronchitis and COPD development has also been studied by Eduard et al. who compared cereal farmers and livestock breeders [61]. They conclude that ranchers suffer from both conditions 
and have a risk of 1.9 for chronic bronchitis and 1.4 for COPD. Earlier research shows that farm dust exposure is associated with COPD development [62]. Analyzing chronic bronchitis in Swiss farmers, Danuser et al. [43] reported a prevalence rate of $16 \%$ and showed a significant increase with age. The most important risk factors for the development of chronic bronchitis are cereal cultivation, age over 60 years, smoking, and indoor exposure longer than $4 \mathrm{~h}$ a day. The prevalence of chronic bronchitis among non-smoker farmers in Switzerland is $12 \%$ and is significantly higher than in the general population (6.8\%).

The effect of occupational exposure in crop farmers in our study is evaluated through their exposure to certain respiratory hazards and by their work activities, exposure to each hazard individually, and combined exposure to several occupational respiratory hazards at the same time. Data are obtained by the self-reported questionnaire on occupational exposure to respiratory hazards. Logistic regression analysis shows that most of the chronic respiratory symptoms are significantly associated with the most common work activities.

Furthermore, certain work processes, such as exposure to dust, smoke, gases, pesticides, and day-to-day activity in crop farmers, and exposure to disinfectants, dust, gases, and vapors, significantly increase the risk of certain chronic respiratory symptoms. Significant effects on age, length of exposure and the combined effect of age, and length of exposure and smoking on individual spirometric parameters were also recorded in EG subjects, and positive, and inverse correlations between mean spirometric parameters were also found, in terms of demographics, smoking habits, and exposure to respiratory hazards among crop farmers.

The Italian study by Talini et al. [37] reported a significant role for certain specific work activities in increasing the prevalence of certain respiratory symptoms, mainly cough and phlegm. These work activities are strongly associated with exposure to endotoxins and organic dust, thus suggesting the possible role of these agents in the etiology of chronic bronchitis. Our previous research indicates a significant association between most chronic respiratory symptoms and plant growing and irrigation [27]. Allday exposure to respiratory hazards in crop farmers is a significant predictive factor for the development of phlegm, dyspnea, and wheezing. In the study of Stoleski et al. [28], subjects who had contact with animals during working hours were up to 5 times more likely to have asthma symptoms than crop farmers, while respiratory symptoms typical of chronic bronchitis are 3 times more common. An Iranian study [63], after adjusting for certain confounding variables, shows that pesticide use in farmers is significantly related to the development of work-related chronic respiratory symptoms. According to the study by Koceva [64], most of the examined parameters in farmers are statistically significantly related to age over 60 years, exposure duration more than 25 years, smoking, smoking experience of more than 20 years, and exposure to chemical hazards (dust, vegetable particles, animal fibers, and pesticides).

Technological advances in agriculture have greatly improved working conditions, but paradoxically increased the intensity and frequency of exposure, such as exposure to organic dust [65], [66]. In addition, engineering controls are often insufficient, the use of safeguards is often inadequate, and occupational exposure to traditional hazards is still dominant as agricultural activities and procedures are not fully standardized, although most of the working population participates in a certain type of agricultural activity [40], [67].

A relatively small number of subjects in the study groups and lack of ambient monitoring may be certain study limitations, with the possibility to interfere with results and potentially aggravate a clear relationship between occupational exposure and respiratory impairment in crop farmers.

\section{Conclusion}

The study results revealed a higher prevalence of respiratory symptoms, and significantly lower values of small airways indices in crop farmers compared to controls and their relation to exposure duration. The results recognized the role of occupational exposure in the development of respiratory symptoms and lung function decline, and confirmed that exposure together with specific workflow activities may be predictors of respiratory health impairment among crop farmers. On the other hand, information on respiratory health in crop farmers is not readily available, and statistics do not always provide a complete picture of the prevalence of chronic respiratory symptoms and diseases due to inadequate reporting or inaccessibility of relevant data. It is therefore necessary to establish their association with specific occupational exposure in agriculture, to apply protocols for their evaluation and to emphasize prevention strategies. These actions should further contribute in critical points detection and indicate the need for adequate preventive measures with obligatory use of respiratory protective equipment, and implementation of engineering controls.

\section{References}

1. Respiratory health hazards in agriculture. Am J Respir Crit Care Med. 1998;158(5):S1-S76. https://doi.org/10.1164/ajrccm.158. supplement_1.rccm1585s1 


\section{PMid:9817727}

2. Kurppa K, Tammaru E, Kempinen M, Rünkla E, Sõrra J, Lehtinen S. Sectoral network on occupational health and safety in agriculture to support enterprises and family farms in Estonia. Ind Health. 2006;44(1):3-5. https://doi.org/10.2486/ indhealth.44.3

PMid:16610524

3. Faria NM, Facchini LA, Fassa AG, Tomasi E. Farm work, dust exposure and respiratory symptoms among farmers. Rev Saude Publica. 2006;40(5):827-36. https://doi.org/10.1590/ s0034-89102005000600016

PMid:17301904

4. Ramazzini B, Wright WC. De Morbis Artificum Diatriba 1713. Chicago: Chicago Press; 1940. https://doi.org/10.1086/ ahr/47.1.114

5. Cuthbert OD, Jeffrey IG, McNeill HB, Wood J, Topping MD. Barn allergy among Scottish farmers. Clin Allergy. 1984;14(2):197206. https://doi.org/10.1111/j.1365-2222.1984.tb02653.x PMid:6705183

6. Iversen M, DahI R, Korsgaard J, Hallas T, Jensen EJ. Respiratory symptoms in Danish farmers: An epidemiological study of risk factors. Thorax. 1988;43(11):872-7. https://doi.org/10.1136/ thx. 43.11 .872

PMid:3222758

7. Iversen M, Pedersen B. Relation between respiratory symptoms, type of farming, and lung function disorders in farmers. Thorax. 1990;45(12):919-23. https://doi.org/10.1136/thx.45.12.919 PMid:2281423

8. Linaker C, Smedley J. Respiratory illness in agricultural workers. Occup Med (Lond). 2002;52(8):451-9.

PMid:12488515

9. Schenker M. Exposures and health effects from inorganic agricultural dusts. Environ Health Perspect. 2000;108 Suppl 4:6614. https://doi.org/10.1289/ehp.00108s4661 PMid:10931784

10. Omland $\varnothing$. Exposure and respiratory health in farming in temperate zones-a review of the literature. Ann Agric Environ Med. 2002;9(2):119-36. PMid: 12498578

11. Langley RL. Consequences of respiratory exposures in the farm environment. N C Med J. 2011;72(6):477-80. PMid:22523860

12. Melbostad E, Eduard W, Magnus P. Determinants of asthma in a farming population. Scand J Work Environ Health. 1998;24(4):262-9. https://doi.org/10.5271/sjweh.319 PMid:9754857

13. Terho EO, Husman K, Vohlonen I. Prevalence and incidence of chronic bronchitis and farmer's lung with respect to age, sex, atopy, and smoking. Eur J Respir Dis Suppl. 1987;152:19-28. PMid:3499342

14. Karadžinska-Bislimovska J, Minov J, Stoleski S, Mijakoski D, Risteska-Kuc S, Milkovska S. Environmental and occupational health risks among agricultural workers living in a rural community near petroleum refinery and motorway in Skopje region. Arh Hig Rada Toksikol. 2010;61(4):415-24. https://doi. org/10.2478/10004-1254-61-2010-2043

PMid:21183433

15. Stoleski S, Karadzinska-Bislimovska J, Minov J, Mijakoski D. Current Needs and Future Development in Macedonian Rural Health Policy. Espoo, Finland: International forum on Occupational Health and Safety, Policies, Profiles and Services; 2011. p. 61. https://doi.org/10.1183/13993003.congress-2018.pa374

16. Donham KJ. Hazardous agents in agricultural dusts and methods of evaluation. Am J Ind Med. 1986;10(3):205-20. https://doi.org/10.1002/ajim.4700100305

PMid: 3532776

17. Mutel C, Doham KJ, Merchant J. Agricultural Respiratory Hazards Education Series. Des Moines: American Lung Association of lowa; 1986

18. Linnainmaa $\mathrm{M}$, Louhelainen $\mathrm{K}$, Eskelinen $\mathrm{T}$. Effect of ventilation on ammonia levels in cowhouses. Am Ind Hyg Assoc J. 1993;54:678-82. https://doi.org/10.1080/15298669391355224

19. Kuchuk AA, Basanets A, Louhelainen K. Bronchopulmonary pathology in workers exposed to organic fodder dust. Ann Agric Environ Med. 2000;7(1):17-23. PMid: 10865240

20. Tarlo SM, Lemiere C. Occupational asthma. N Engl J Med. 2014;370(7):640-9. PMid:24521110

21. Minette A. Questionnaire of the European community for coal and steel (ECSC) on respiratory symptoms. 1987-updating of the 1962 and 1967 questionnaires for studying chronic bronchitis and emphysema. Eur Respir J. 1989;2(2):165-77. PMid:2703044

22. Variations in the prevalence of respiratory symptoms, selfreported asthma attacks, and use of asthma medication in the European community respiratory health survey (ECRHS). Eur Respir J. 1996;9(4):687-95. https://doi.org/10.1183/09031936.9 6.09040687

PMid:8726932

23. World Health Organization. Guidelines for Controlling and Monitoring the Tobacco Epidemic. Geneva: World Health Organization; 1998.

24. Smoking Pack-Years; 2013. Available from: http://www. smokingpackyears.com/calculate. [Last accessed on 2019 Apr 15]

25. US Department of Health and Human Services. The Health Consequences of Smoking: Chronic Obstructive Pulmonary Disease. A report of the Surgeon General; 1984. Available from: http://www.profiles.nlm.nih.gov/ps/access/nnbccs.pdf. [Last accessed on 2019 Mar 16].

26. Quanjer PH, Tammeling GJ, Cotes JE, Pedersen OF, Peslin R, Yernault JC. Lung volumes and forced ventilatory flows. Report working party standardization of lung function tests, European community for steel and coal. Official statement of the European respiratory society. Eur Respir J Suppl. 1993;16:5-40. https:// doi.org/10.1183/09041950.005s 1693 PMid:8499054

27. Stoleski S, Minov M, Karadzinska-Bislimovska J, Mijakoski D Chronic respiratory symptoms and lung function in a sample of agricultural workers in Skopje region. Maced J Med Sci. 2014;7(2):327-34. https://doi.org/10.3889/oamjms.2014.057

28. Stoleski S, Minov J, Karadzinska-Bislimovska J, Mijakoski D. Bronchial hyperresponsiveness in farmers: Severity and workrelatedness. Maced J Med Sci. 2014;7(3):536-43. https://doi. org/10.3889/oamjms.2014.097

29. Stoleski S, Minov J, Mijakoski D, Karadzinska-Bislimovska J Chronic respiratory symptoms and lung function in agricultural workers-influence of exposure duration and smoking. Open Access Maced J Med Sci. 2015(1);3:158-65. https://doi. org/10.3889/oamjms.2014.057

PMid:27275215

30. Bongers P, Houthuijs D, Remijn B, Brouwer R, Biersteker K. Lung function and respiratory symptoms in pig farmers. $\mathrm{Br} \mathrm{J}$ Ind Med. 1987;44(12):819-23. https://doi.org/10.1136/oem.44.12.819 PMid:3689717

31. Karadzinska-Bislimovska J, Minov J, Stoleski S, Mijakoski D, Risteska-Kuc S. Respiratory symptoms, atopic status and lung function tests in agricultural workers. Allergy. 2007;62(83):283. 
https://doi.org/10.1155/2011/267542

32. Terho EO. Work-related respiratory disorders among Finnish farmers. Am J Ind Med. 1990;18(3):269-72. https://doi. org/10.1002/ajim.4700180305

PMid:2220830

33. Warren CP, Manfreda J. Respiratory symptoms in Manitoba farmers: Association with grain and hay handling. Can Med Assoc J. 1980;122(11):1259-64.

PMid:7388722

34. Heederik D, Pouwels H, Kromhout H, Kromhout D. Chronic nonspecific lung disease and occupational exposures estimated by means of a job exposure matrix: The Zutphen study. Int J Epidemiol. 1989;18(12):382-9. https://doi.org/10.1093/ ije/18.2.382

PMid:2767852

35. Kauffmann F, Drouet D, Lellouch J, Brille D. Occupational exposure and 12-year spirometric changes among Paris area workers. $\mathrm{Br} \mathrm{J}$ Ind Med. 1982;39(3):221-32. https://doi. org/10.1136/oem.39.3.221

PMid:7093148

36. Magarolas R, Monsó E, Aguilar X, Radon K, Nowak D, Martínez C, et al. Prevalence and risk factors of respiratory symptoms in farmers; comment. Med Clin (Barc). 2000;114(18):685-9. PMid:10916788

37. Talini D, Monteverdi A, Carrara M, Paggiaro PL. Risk factors for chronic respiratory disorders in a sample of farmers in middle Italy. Monaldi Arch Chest Dis. 2003;59(1):52-5.

38. Skórska C, Mackiewicz B, Dutkiewicz J, Krysińska-Traczyk E, Milanowski J, Feltovich $\mathrm{H}$, et al. Effects of exposure to grain dust in Polish farmers: Work-related symptoms and immunologic response to microbial antigens associated with dust. Ann Agric Environ Med. 1998;5(2):147-53

PMid:9860817

39. Chan-Yeung M, Dimich-Ward H, Enarson DA, Kennedy SM. Five cross-sectional studies of grain elevator workers. Am J Epidemiol. 1992;136(10):1269-79. https://doi.org/10.1093/ oxfordjournals.aje.a116435

PMid:1476149

40. Kimbell-Dunn MR, Fishwick RD, Bradshaw L, ErkinjunttiPekkanen R, Pearce N. Work-related respiratory symptoms in New Zealand farmers. Am J Ind Med. 2001;39(3):292-300. https://doi.org/10.1002/1097-0274(200103)39:3<292:aidajim1017>3.0.co;2-f

PMid:11241562

41. Radon K, Winter C. Prevalence of respiratory symptoms in sheep breeders. Occup Environ Med. 2003;60(10):770-3. PMid:14504366

42. Radon K, Danuser B, Iversen M, Jörres R, Monso E, Opravil U, et al. Respiratory symptoms in European animal farmers. Eur Respir J. 2001;17(4):747-54. https://doi.org/10.1183/09031936 01.17407470

PMid:11401073

43. Danuser B, Weber C, Künzli N, Schindler C, Nowak D. Respiratory symptoms in Swiss farmers: An epidemiological study of risk factors. Am J Ind Med. 2001;39(4):410-8. https:// doi.org/10.1002/ajim.1032

PMid:11323791

44. Kern J, Mustajbegovic J, Schachter EN, Zuskin E, VrcicKeglevic M, Ebling Z, et al. Respiratory findings in farmworkers. J Occup Environ Med. 2001;43(10):905-13. https://doi. org/10.1097/00043764-200110000-00010 PMid:11665460

45. Talini D, Monteverdi A, Benvenuti A, Petrozzino M, Di Pede F, Lemmi $\mathrm{M}$, et al. Asthma-like symptoms, atopy, and bronchial responsiveness in furniture workers. Occup Environ Med. 1998;55(11):786-91. https://doi.org/10.1136/oem.55.11.786 PMID: 9924457

46. Omland O, Sigsgaard T, Pedersen OF, Miller MR. The shape of the maximum expiratory flow-volume curve reflects exposure in farming. Ann Agric Environ Med. 2000;7(2):71-8. PMid:11153034

47. Zock JP, Sunyer J, Kogevinas M, Kromhout H, Burney $P$, Antó JM. Occupation, chronic bronchitis, and lung function in young adults. An international study. Am J Respir Crit Care Med. 2001;163(7):1572-7. https://doi.org/10.1164/ ajrccm.163.7.2004195 PMid:11401876

48. Zuskin E, Mustajbegovic J, Schachter EN, DokoJelinic J. Respiratory function of textile workers employed in dyeing cotton and wool fibres. Am $\mathrm{J}$ Ind Med. 1997;31(3):344-52. https://doi.org/10.1002/ (sici)1097-0274(199703)31:3<344:aid-ajim11>3.0.co;2-0

49. Ulvestad B, Bakke B, Eduard W, Kongerud J, Lund MB. Cumulative exposure to dust causes accelerated decline in lung function in tunnel workers. Occup Environ Med. 2001;58(10):663-9. https://doi.org/10.1136/oem.58.10.663 PMid:11555688

50. Janson C, Anto J, Burney P, Chinn S, de Marco R, Heinrich J, et al. The European community respiratory health survey: What are the main results so far? European community respiratory health survey II. Eur Respir J. 2001;18(3):598-611. https://doi. org/10.1183/09031936.01.00205801

PMid:11589359

51. Dosman JA, Graham BL, Hall D, Van Loon P, Bhasin P, Froh F. Respiratory symptoms and pulmonary function in farmers. J Occup Med. 1987;29(1):38-43. https://doi.org/10.1002/ ajim.4700170111

PMid:3819883

52. Huy T, De Schipper K, Chan-Yeung M, Kennedy SM. Grain dust and lung function. Dose-response relationships. Am Rev Respir Dis. 1991;144(6):1314-21. https://doi.org/10.1164/ ajrccm/144.6.1314 PMid:1741544

53. Corey P, Hutcheon M, Broder I, Mintz S. Grain elevator workers show work-related pulmonary function changes and dose-effect relationships with dust exposure. Br J Ind Med. 1982;39(4):3307. https://doi.org/10.1136/oem.39.4.330 PMid:7138793

54. Enarson DA, Vedal S, Chan-Yeung M. Rapid decline in FEV1 in grain handlers. Relation to level of dust exposure. Am Rev Respir Dis. 1985;132(4):814-7. https://doi.org/10.1164/ ajrccm/138.6.1584 PMid:4051318

55. Dalphin JC, Pernet D, Dubiez A, Debieuvre D, Allemand H, Depierre A. Etiologic factors of chronic bronchitis in dairy farmers. Case control study in the Doubs region of France. Chest. 1993;103(2):417-21. https://doi.org/10.1378/chest.103.2.417 PMid:8432130

56. Djuricić S, Minić P, Radovanović S, Babić DD, Gavrilov M. Basic spirometry measurements in workers on pig farmers. Srp Arh Celok Lek. 2004;132(3-4):85-91. https://doi.org/10.2298/ sarh0404085d

PMid:15307309

57. Dalphin JC, Dubiez A, Monnet E, Gora D, Westeel V, Pernet D, et al. Prevalence of asthma and respiratory symptoms in dairy farmers in the French province of the Doubs. Am J Respir Crit Care Med. 1998;158(5):1493-8. https://doi.org/10.1164/ ajrccm.158.5.9709108

PMid:9817698 
58. Tashkin DP, Detels R, Simmons M, Liu H, Coulson AH, Sayre $\mathrm{J}$, et al. The UCLA population studies of chronic obstructive respiratory disease: XI. Impact of air pollution and smoking on annual change in forced expiratory volume in one second. Am J Respir Crit Care Med. 1994;149(5):1209-17. https://doi. org/10.1164/ajrccm.149.5.8173761

PMid:8173761

59. Sigsgaard T, Hjort C, Omland $\varnothing$, Miller MR, Pedersen OF. Respiratory health and allergy among young farmers and nonfarming rural males in Denmark: The SUS study. J Agromedicine. 2004;9(2):223-38. https://doi.org/10.1300/j096v04n01_09 PMid: 19785218

60. Gautrin D, Ghezzo H, Infante-Rivard C, Malo JL. Incidence and host determinants of work-related rhinoconjunctivitis in apprentice pastry-makers. Allergy. 2002;57(10):913-8. https:// doi.org/10.1034/j.1398-9995.2002.23636.x

PMid:12269937

61. Eduard W, Pearce N, Douwes J. Chronic bronchitis, COPD, and lung function in farmers: The role of biological agents. Chest. 2009;136(3):716-25. https://doi.org/10.1378/chest.08-2192 PMid:19318669

62. Husman K, Koskenvuo M, Kaprio J, Terho EO, Vohlonen I. Role of environment in the development of chronic bronchitis. Eur $\mathrm{J}$ Respir Dis Suppl. 1987;152:57-63.

PMid:3499347
63. Hashemi N, Mirsadraee M, Shakeri MT, VarastehAR. Prevalence of work-related respiratory symptoms in Iranian farmers. Can Respir J. 2006;13(4):198-202. https://doi.org/10.1155/2006/967895 PMid:16779464

64. Koceva I. Respiratory symptoms in the last 12 months, spirometric parameters, and ventilatory function in agricultural workers. In: Book of Abstracts, Second Macedonian Congress of Occupational Medicine with International Participation, Skopje; 2016.

65. Kirkhorn SR, Schenker MB. Current health effects of agricultural work: Respiratory disease, cancer, reproductive effects, musculoskeletal injuries, and pesticide-related illnesses. J Agric Saf Health. 2002;8(2):199-214. https://doi. org/10.13031/2013.8432

PMid:12046806

66. Radon K, Monso E, Weber C, Danuser B, Iversen M, Opravil U, et al. Prevalence and risk factors for airway diseases in farmerssummary of results of the European farmers' project. Ann Agric Environ Med. 2002;9(2):207-13. https://doi.org/10.1183/090319 36.01 .17407470

PMid:12498590

67. Rachiotis G, Savani R, Brant A, MacNeill SJ, Newman Taylor A Cullinan P. Outcome of occupational asthma after cessation of exposure: A systematic review. Thorax. 2007;62(2):147-52. https://doi.org/10.1136/thx.2006.061952

PMid:17040933 